\title{
Scientific-based pictorial storybook with project-based learning method for improving the critical thinking skills of elementary school students
}

\author{
Dini Aria Farindhani * ${ }^{\text {, Muhammad Nur Wangid }}{ }^{2}$ \\ ${ }^{1}$ SD Negeri Ketanggungan 04. Jalan Pesantren No. 13, Ketanggungan, Brebes, Indonesia \\ ${ }^{2}$ Department of Primary Education, Program Pascasarjana, Universitas Negeri Yogyakarta. \\ Jalan Colombo No. 1, Karangmalang, Yogyakarta, 55281, Indonesia. \\ * Corresponding Author. Email: aria_farindhani@yahoo.com \\ Received: 27April 2016; Revised: 29 December 2018; Accepted: 21 May 2019
}

\begin{abstract}
The study aims at developing a scientific-based pictorial storybook with PjBL method for improving the critical thinking skills of the elementary school students. The research and development initiative refer to the design of Borg \& Gall with 10 stages of test. Then, during the conduct of the study the data were gathered by means of product assessment sheet, teacher response questionnaire, student response questionnaire and critical thinking skills test. For the data analysis, the data were analysed by means of paired t-test with significance rate 5\%. The results of the study show that the scientific-based pictorial storybook with PjBL method has been feasible for improving the critical thinking skills of the elementary school students. Based on the paired t-test results with the significance rate 5\% (sig. (2tailed) $=0.000<\alpha=0.05$ ), after the implementation the critical thinking skills of the students increase significantly.

Keywords: pictorial storybook, scientific approach, project-based learning method, critical thinking

How to Cite: Farindhani, D., \& Wangid, M. (2019). Scientific-based pictorial storybook with project-based learning method for improving the critical thinking skills of elementary school students. Jurnal Prima Edukasia, 7(1), 94-105. doi:https://doi.org/10.21831/jpe.v7i1.8807

d

https://doi.org/10.21831/jpe.v7i1.8807
\end{abstract}

\section{Introduction}

The learning process of Curriculum 2013 emphasizes how to facilitate the students to perform critical thinking skills in every activity that they perform and also to be creative in discovering and developing their skills. Elementary school students belong to the operational concrete intellectual level; in this level, the students should have been able to solve concrete problems by using their logics but in the practice the students have not been able to solve the abstract problems. As a result, the teachers should understand the skills and capacities that their students have.

According to the learning process of 2013 Curriculum, the students are demanded to be able to apply their experience into the activities of solving their problems (Sinambela, 2017). Basically, students use the logics that they have mastered to solve the problems that they encounter. With regards to the logics, or the thinking process within the logics, the thinking skills are divided into two categories namely the higher order thinking skills and the lower order thinking skills (Dini, 2018). For solving problems, students should perform their higher order thinking skills; however, the mastery of higher order thinking skills demand in-depth understanding. Duran \& Bosch (2011, p.1) states that critical thinking is the main part of completing all six levels in the Bloom's taxonomy.

Critical thinking skills refer to the skills that focus on an event or a problem. The event or the problem is reviewed by analysing the factors of the cause behind the event or the problem, the individuals who have been involved in the cause and how the event or the problem has occurred. Departing from the analysis, the students will be able to find the solution for the event or the problem. Through the analysis as well, the students will not be quickly making their decisions. Their decisions might be taken based on the facts that have been found instead of their understanding. This statement is in accordance to the opinion by Santrock (2017, p.353), which states that critical thinking is an activity of performing 
Jurnal Prima Edukasia, 7 (1), 2019 - 95

Dini Aria Farindhani, Muhammad Nur Wangid

reflective and productive thinking and of evaluating evidence.

Based on the above elaboration, it might be implied that critical thinking skills should be exercised since the childhood so that these skills might be continuously developed and become the tools for the study in dealing with bigger problems as they grow up. Critical thinking skills cause students to be more active in looking for information that supports truth. Students who exercise their critical thinking skills in every single activity will be assisted in solving problems, making decisions, raising questions, making plans, performing assessment and investigating truth (Rasiman, 2012). The exercise of critical thinking skills among students aims at encouraging the students to think and act quickly and responsively. Therefore, the critical thinking skills are necessary for dealing with the phenomena that the students find in their daily life.

The activities that demand the exercise of critical thinking skills are: (1) defining the theme that will be observed, gathering information from multiple sources and confirming the appropriate information during the observation; (2) identifying similarities or contradictions and selecting the topic of problems based on the available information; (3) being able to differentiate the value of information from opinion, prioritizing important information and discerning opinions from facts; (4) being able to consider alternative possibilities and developing new hypotheses; (5) performing contextual analysis in relation to the consideration of history, ethics, politics, culture, environment and certain situations; and (6) drafting questions and conclusion test altogether with the reflection over the results of the test. According to Thyer (2013, p.3), those skills might be categorized into six main dimensions of thinking within the critical thinking skills namely observation, analysis, evaluation, question, consideration and reflection.

The learning process of 2013 Curriculum does not only focus on the cognitive aspect but also on the behavioural aspect and the psychomotor aspect. Specifically, in the case of the study there are associations between the cognitive aspect and the behavioural aspect within the learning process of 2013 Curriculum. This statement is in accordance to the statement by Savage \& Wehman $(2014$, p.1): the development of critical thinking skills indirectly improves the other skills that the students have such as problem-solving skills since critical thinking skills need communication as the medium for delivering the intention of the thinking process.

Departing from the above elaboration, the researcher would like study the case further by means of interview and observation. The interview and the observation are related to the conduct of the learning process of 2013 Curriculum. The interview was performed on November $7^{\text {th }}$, $14^{\text {th }}$ and $16^{\text {th }}, 2016$ in the Second Grade of Serayu Public Elementary School, Joannes Bosco Elementary School and Muhammadiyah Elementary School Gendeng. The results of the interview to the teachers from the three schools show that the teachers need interesting supplement books of 2013 Curriculum that might support the conduct of their teaching-learning activities since they only rely on the books of 2013 Curriculum that have been provided by the government. Similarly, the results of the observation to the three schools show that the teachers have only relied on the books of 2013 Curriculum that have only been provided by the government. Then, from the perspective of the students, the students to less develop their critical thinking skills and this lack of development on their critical thinking skills is caused by the students' lack of communication on the materials that they have been learning during the learning activities. In addition, another problem is that the students rarely apply the understanding that they have studied in the classroom for solving (analysing and evaluating) the problems in the context of their daily life.

In addition, the researcher also perform observation on the library of the three schools after the learning process has ended. The results of the observation toward the library show that the library of the three schools indeed has abundant number of books but none of these books might be benefitted as the supplement books of 2013 Curriculum. Many books have been found in the library but most of these books are story books and fairy tales. Consequently, these books might not be benefitted as the supplement books of 2013 Curriculum since the books that might be benefitted as the supplement books of 2013 Curriculum should be the ones that meet the criteria of teaching materials. The Department of National Education (Departemen Pendidikan Nasional Republik Indonesia, 2008, p. 28) states that teaching materials should meet four components namely the components of content feasibility, the components of language feasibility, the components of presentation feasibility and the components of graphic feasibility. In relation to these components, the books that 
Jurnal Prima Edukasia, 7 (1), 2019 - 96

Dini Aria Farindhani, Muhammad Nur Wangid

have been found in those three elementary schools have not met the components of content feasibility and the components of presentation feasibility in accordance to the books of 2013 Curriculum. Such mismatch of teaching materials has also been found by (Fithriyyati \& Maryani, 2018; Purnomo \& Wilujeng, 2016, pp.67-78), which results in the less effective teaching materials.

Then, with regards to teaching materials, the teachers from the three schools have not tried to benefit the pictorial storybook as their learning materials. However, the teachers will be interested if the pictorial storybook might be benefitted as one of the teaching materials that support the teaching learning activities. The reason is that creating teaching materials might take more time and it might be difficult to perform since the teachers still have several administrative tasks. Not to mention, the procurement of teaching materials only for a single classroom might be costly. Despite this situation, the teachers still demand teaching materials that might be implemented in their classroom. In relation to the statement, the pictorial storybook-learning materials are expected to not only contain the stories that entertain but also the stories that encourage learning process among the students. According to Rossiter, Derwing, \& Jones (2008, pp.325339), the pictorial storybook-learning materials should contain logical and clear story.

Next, with regards to critical thinking skills, the teachers used to administer narrative test items for the students but the responses of their students do not meet the teachers' expectation. There were only four students who had been able to respond to the narrative test items correctly. The possibility is that the teachers do not supply the higher order thinking skills in the narrative test items with the various learning methods. The teachers admit that they used to implement the role play method in the learning activities but the implementation did not return in great success because there were only 6 students who had performed the role play while the other students had been busy with themselves. This is very possible because the role play has been implemented to the students of Second Grade, which is not inappropriate.

Basically, there are many learning methods that the teachers might implement for developing the students' capacity. One of the methods that they might implement is the PjBL or Project-Based Learning. The PjBL Method might even be implemented for developing the critical thinking skills. PjBL is a learning method that consists of scientific learning activities namely project planning, project launch, guided inquiry and product creation and also project conclusion (Mergendoller, Markham, Ravitz, \& Larmer, 2006, p.14). These scientific activities are fit into the scientific approach within the learning process of 2013 Curriculum. The learning process in the PjBL Method centers on the students, focuses on the analysis of problemsolving activities by applying the concepts that have been studied, encourage the students to perform investigation in order to find facts and is realistic (Gülbahar \& Tinmaz, 2006, p.310). Thus, these scientific activities demand the students to perform active thinking skills and the implementation of the active thinking skills demand communication in order to that the students might deliver their ideas. In addition, in the PjBL Method the role that the teachers should play is facilitator with the students as the focus of the learning process since the students should discover their own knowledge and grasp their own meaningfulness.

The PjBL method might be implemented with the scientific approach because this method has several scientific activities that might be combined. The scientific approach is identical to the five scientific activities namely observing, raising questions, gathering information, processing information and communicating the results of the activities (Kurniasih \& Sani, 2014, p.153). In the same time, the activities within the PjBL method consist of project preparation, project design, project launch and project communication (Mergendoller et.al. 2006, p.11). The scientific activities might be inserted in the activities in the PjBL method with the following composition: (a) the observing and raising questions activity might be inserted into the project preparation; (b) the information gathering activity might be inserted into the project design; (c) the associating activity might be inserted into the project launch; and (d) the communicating activity might be inserted into the project communication. This combination fits into the results of the study by Juano \& Pardjono (2016, pp.46-53), which show that the implemented of PjBL method is able to improve the students' thinking skills.

Unfortunately, interesting learning materials that contain scientific activities and PjBL method have not been available yet. Therefore, interesting learning materials with variative colours and pictures should be 
Jurnal Prima Edukasia, 7 (1), 2019 - 97

Dini Aria Farindhani, Muhammad Nur Wangid

developed and the development of such learning materials might take the form of pictorial storybook. The pictorial storybook-learning materials might help the students to learn independently by developing their skills and capacities. The pictorial storybook does not only focus on the picture but also the scientific approach and the PjBL method that the characters in the story perform since the basically the plot of the pictorial storybook might be developed naturally and logically. The statement has been supported by the results of a study by Donoghue (2009, p.5), which state that within a good pictorial storybook there should be actions/activities of credible and logical characters and development of natural behaviours that want to be highlighted from the characters.

Through the scientific approach-based pictorial storybook-learning materials with $\mathrm{PjBL}$ method, the students are expected to habituate critical, creative and communicative thinking skills in dealing with the challenges within their world. By performing critical thinking skills, the students might solve their problems by first analysing the cause and effect of their problems. Then, departing from the results of their analysis the students might find the solutions and the solutions might be contemplated in the long term. Furthermore, the students are expected to completely solve their problems based on the knowledge or the understanding that has been attained from the application of science, experience and actual experience so that they will not jump too quick to the conclusion. This description fits into the results of a study by Anisa (2017, pp. 1-11), which show that the implementation of scientific activities and PjBL method has been able to improve the students' critical thinking skills.

\section{Method}

The development of the scientific-based pictorial storybook-learning materials with the PjBL method referred to the Borg and Gall Model (1983, pp.775-776). Then, the product development test, namely the test toward the scientificbased pictorial storybook-learning materials with the PjBL method consisted of the following stages: (1) product validation by language expert and material expert and product validation based on the results of FGD; (2) revision in accordance to the validation results; (3) preliminary field test; (4) revision based on the preliminary field test results; (5) main field test; (6) revision based on the main field test results; (7) operational field test; and (8) revision based on the operational field test results.

The subjects in the preliminary field test were 6 students from Second Grade of Serayu Public Elementary School Yogyakarta and the subject selection was based on the category of low critical thinking skills, moderate critical thinking skills and high critical thinking skills. Then, the subjects in the main field test were 12 students from Second Grade of Joannes Bosco Elementary School and the subject selection was based on the category of low critical thinking skills, moderate critical thinking skills and high critical thinking skills. Next, the subjects in the operational field test were the Second-Grade students from the following elementary schools: (1) Serayu Public Elementary School; (2) Joannes Bosco Elementary School; and (3) Muhammadiyah Elementary School Gendeng. The subjects in these elementary schools are divided into two experimental groups (Serayu Public Elementary School and Joannes Bosco Elementary School) and one control group (Muhammadiyah Elementary School Gendeng).

The research instrument in the research and development initiative was divided into two parts. The first part of the instrument measured the feasibility of the teaching materials and consisted of: (1) questionnaire of validation by language expert; (2) questionnaire of validation by material expert; (3) questionnaire of teacher response on the product that had been developed; (4) questionnaire of student response on the product that had been developed; and (5) narrative test items on critical thinking skills. Then, the data in the study consisted of the validation data from the media expert and the validation data from the material expert with regards to the feasibility of the product that had been developed (namely the scientific approach-based pictorial storybook-learning material with $\mathrm{PjBL}$ method), the data from the teacher response toward the product that had been developed, the data from the student response toward the product that had been developed and the data from the results of the narrative test items administration.

Within the research and development initiative, the data were analysed in order to identify the feasibility of the teaching materials that had been developed in order to improve the students' critical thinking skills. Then, in order to identify the quality of the scientific approachbased pictorial storybook-learning materials with PjBL method, the researcher distributed the questionnaire of teacher response and the 
Jurnal Prima Edukasia, 7 (1), 2019 - 98

Dini Aria Farindhani, Muhammad Nur Wangid

questionnaire of student response that consisted of four aspects namely the aspect of content feasibility, the aspect of language, the aspect of graphic and the aspect of material presentation. After the quantitative data had been attained, the researcher performed the qualitative data analysis by referring to the guidelines of four-scale score conversion with the following categories: (1) Very Good; (2) Good; (3) Poor; and (4) Very Poor.

\section{Results and Discussions}

Results

The product development starts with the design of the preliminary part, the middle part and the final part of the product. The preliminary part of the product contains title page, owner appreciation page, cubcover, book type, character introduction, table of content, direction and forewords. Then, the middle part of the product contains sub-theme delivery, learning objectives and body of the story. Next, the final part of the product contains references, glossary, author's biography and book synopsis. Then, the composition of the title page is related to selecting pictures that are relevant to the Theme 6 and the PjBL method.

The product that has been developed consists of three sub-themes and each sub-theme contains a story that refers to the scientific activities in the PjBL method. In addition, each sub-theme integrates the learning materials from several subjects; for example, Sub-Theme 1 integrates the learning materials from four subjects namely Mathematics, Bahasa Indonesia, Art and Craft and Citizenship Education. The materials in Sub-Theme I are related to the events that have occurred in the surrounding environment. These materials are designed by integrating the learning materials from the four subjects into a coherent/ flexible story by introducing the characters that perform the activities of the scientific approach and the PjBL method namely observing and raising questions (preparation), gathering information (design), associating (implementation) and communicating (communication).

The critical thinking skills are developed through the activities of the characters that invite the students to perform the scientific activities. The activities of these characters should be relevant to the scientific activities in the scientific approach and the PjBL method. These activities are observing and raising questions (preparation), gathering information (design) and associating (implementation). The skills that might be demanded by these activities from the preparation until the implementation requires in-depth thinking process since the students are demanded to discover their own skills by looking for the solutions through the consideration toward the cause, the effect and the actual facts. In relation to the activities that develop the critical thinking skills within the characters of the story, the teaching materials should also contain narrative test items that contain opinion, occurrence and problems in which the students are demanded to find their answer or solve their problems.

Each sub-theme consists of stories that contain the relevant learning materials and these stories are presented through texts and illustrations of the characters. The characters in these stories are depicted to perform experiment, to solve problems and to design the project. The texts in these learning materials are composed of simple vocabularies with the font size 16 so that the students might read and understand these texts easily. Then, the font type that has been selected is Sans Serif in order to draw the interest of the students when the pictorial-storybook learning-materials are implemented in the teaching-learning activities.

As having been explained, the product that has been developed is a scientific approach-based pictorial-storybook learning-materials. Since the product is part of learning materials, the product should meet the requirements of a good learning material. The aspects that should be meet are namely: (1) aspect of content concordance; (2) aspect of language; (3) aspect of material presentation; (4) aspect of graphic; (5) aspect of PjBL content and scientific content; and (6) aspect of usefulness.

The aspects of assessment for the pictorialstorybook are validated by the language expert and the material expert. In addition, these aspects are validated based on the results of FGD. In other words, the data in the research and development are the data from the assessment toward the feasibility of the pictorial-storybook that have been provided by the language expert, the material expert and the FGD. The validation itself aims at attaining feedback and suggestions for revisions so that the learning materials might be categorized "Feasible" prior to its implementation in the preliminary test. After the scientific approach-based pictorial-storybook learning materials with the PjBL method have been considered "Feasible," the product is sent to the preliminary test. The summary on the data from 
Jurnal Prima Edukasia, 7 (1), 2019 - 99

Dini Aria Farindhani, Muhammad Nur Wangid

the results of the assessment by the material expert might be consulted in Table 1 .

Table 1. Results of Feasibility Assessment for the Pictorial Storybook by Material Expert

\begin{tabular}{lcc}
\hline \multicolumn{1}{c}{ Aspects } & Mean & \multicolumn{1}{c}{ Category } \\
\hline Content Concordance & 3.80 & Very Feasible \\
Material Presentation & 3.70 & Very Feasible \\
Scientific and PjBL & 3.60 & Very Feasible \\
Content & & \\
Usefulness & 3.90 & Very Feasible \\
\hline
\end{tabular}

Based on the results in Table 1, it is apparent that the scientific approach-based pictorial storybook learning materials with the $\mathrm{PjBL}$ method that has been developed ad validated by the material expert is considered "Feasible for Implementation with Revision." Then, each of the aspects that have been mentioned consist of several indicators. First, the aspect of content concordance consists of indicator clarity, concordance to Theme 6 and subject integration. Second, the aspect of material presentation consists of presentation sequence concordance and information completeness. Third, the aspect of PjBL content consists of subject facts and concordance between the characters in the story and the scientific activities (observing, raising question, gathering information, reasoning and communicating). Fourth, the aspect of usefulness consists of concordance of children's cognitive development, children's active involvement and environmental care. With regards to the revision, the suggestions that have been provided to the revision of the scientific approach-based pictorial-storybook learning materials with the PjBL method are as follows: (1) the texts should be clear; (2) the language should be simple; and (3) the wordings should be given attention because there are still some errors on the letters.

In addition to having been validated by the material expert, the scientific approach-based pictorial-storybook learning materials with the $\mathrm{PjBL}$ method is also validated by the language expert. The assessment from the language expert does not only focus on the aspect of the language but also the aspect of the graphic in the product. The assessment results from the validation of the language expert are similar to that of the material expert; both validations implement the four-point Likert scale. The summary from the results of the language expert assessment might be consulted in Table 2.
Table 2. Assessment Results of PictorialStorybook by Language Expert

\begin{tabular}{lrc}
\hline \multicolumn{1}{c}{ Aspect } & Mean Score & Category \\
\hline Language & 3.80 & Very Feasible \\
Graphic & 3.80 & Very Feasible \\
Usefulness & 4.00 & Very Feasible \\
\hline
\end{tabular}

Based on the results in Table 2, it is apparent that the scientific approach-based pictorial-storybook learning materials that has been developed and validated by the language expert is considered "Feasible for Implementation with Revision." Within this assessment, the aspect of language consist of the following indicators: (1) readability; (2) concordance between the setting of time and the setting of place; (3) sentence structure integrity; (4) concordance on the punctuation; (5) concordance on page number; (6) consistency on capital letter use; and (7) concordance on font type. On the other hand, within this assessment the aspect of graphic consists of the following indicators: (1) concordance on book size; (2) concordance on cover design; (3) concordance on page number; (4) concordance on color selection; (5) concordance between texts and illustrations; (6) concordance between illustrations and meanings; (7) concordance on textures; and (8) concordance on book form. Last but not the least, the aspect of usefulness only consist of a single indicator namely children's emotional development. With regards to the revision, the suggestions that have been provided to the scientific approach-based pictorial-storybook learning materials are as follows: (1) the sentences should be made simple; (2) the punctuation should be consisten; and (3) the font type should e changed; and (4) the unaligned texts should be made aligned.

After having been validated by the material expert and the language expert, the scietific approach-based pictorial-storybook learning materials with the PjBL method is also validated through the FGD session. The results of the FGD session shbow that the scientific approach-based pictorial-storybook learning materials with the PjBL method should be revised. The revisions are as follows: (1) the font type should be changed; (2) the eyes should be made sparkling; (3) the illustrations should be added; and (4) the colour variation should be added. The revisions that have been provided by the material expert and the language expert and that have also been gathered from the FGD session should be followed up in order that the scientific approach-based pictorialstorybook learning materials might be sent into 
the test by the teachers and the students for gathering their response. Eliciting the response by both the teachers and the students aims at identifying the opinions from both the teachers and the students toward the product.

The results of the teacher response questionnaire show that the product belongs to the "Very Feasible" category. Similarly, the results of the student response questionnaire show that the product belongs to the "Very Feasible" category. Based on the results of the two response questionnaires, it might be concluded that the scientific approach-based pictorial-storybook learning materials with the $\mathrm{PjBL}$ method is very feasible for implementation in the teaching learning process. After the product has been tested to the teachers and the students, the product is sent to the effectiveness test. The effectiveness test is performed in order to identify the effectiveenss of the product for improving the students' critical thinking skills.

The conduct of the product effectiveness test involves two groups of students namely the experimental group and the control group. The effectiveness test is performed on Theme 6 with the Sub-Theme 1, Sub-Theme 2 and Sub-Theme 3. After the product effectiveness test has been completed, the researcher proceeds to the conduct of the operational test. The method that has been selected in the conduct of the operational test is the quasi-experimental method. Then, the experimental group consists of the Second Grade students from the Serayu Public Elementary School and the Joannes Bosco Elementary School while the control group consists of the Muhammadiyah Elementary School Gendeng. The conduct of the operational test aims at identifying the effectiveness of the scientific approach-based pictorial-storybook learning materials with the PjBL method for improving the critical thinking skills of the Second Grade students. In conducting the operational test, the researcher should design the pre-test items and the post-test items for measuring the students' critical thinking skills.

The results of the students' critical thinking skills in the operational test consist of the students' test score from the narrative test items within the operational test. In order to identify the students' critical thinking skills, the students' test score should be analyzed by means of descriptive statistics. The results of the students' descriptive statistics calculation in the pre-test and the post-test might be consulted in Figure 1.

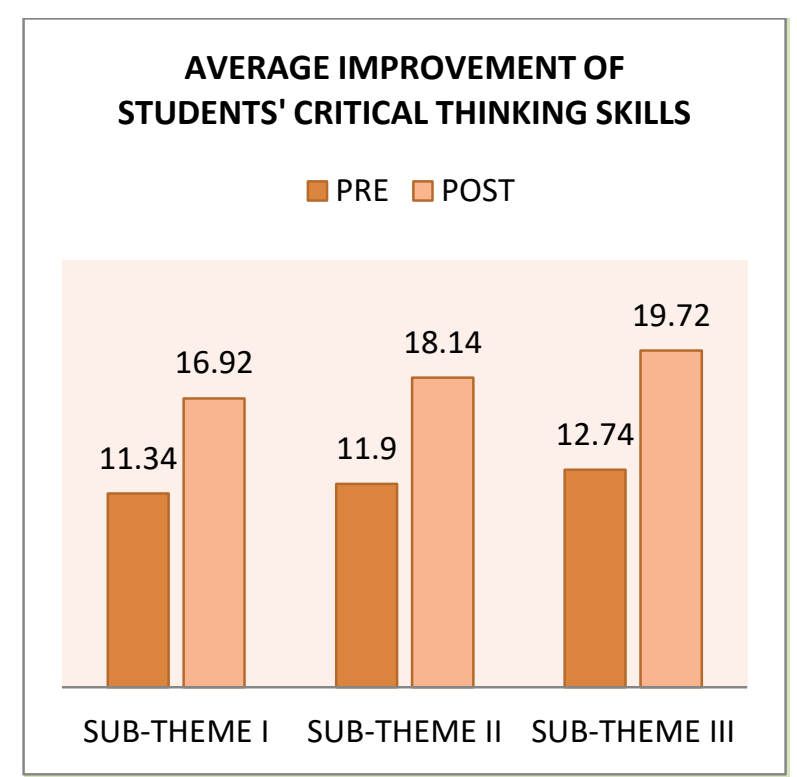

Figure 1. Graphic on the Improvement of the Students' Critical Thinking Skills

Departing from the results in Figure 1, it is clear that the learning process that implements the scientific approach-based pictorial-storybook learning materials with the PjBL method has improved the students' critical learning skills. The improvement might be found in the pre-test score and the post-test score from each sub-theme that has been taught. However, in order to ensure whether the improvement is significant or not, a paired t-test should be performed. Therefore, the data should go through the prerequisite test in the form of normality test and homogeneity test.

With regards to the previous elaboration, the effectiveness test might be performed by means of the independent sample t-test and the paired sample t-test. By doing so, whether the improvement of the students' critical thinking skills is significant or not might be identified. Then, the independent sample t-test is performed in order to identify the effectiveness of the product between the experimental group and the control group while the paired sample t-test is performed in order to identify the effectiveness of the product between the pre-experiment group and the post-experiment group. The results of the independent sample t-test might be consulted in Table 3.

Table 3. Results of Independent Sample t-test for the Students' Critical Thinking Skills

\begin{tabular}{lcr}
\hline & \multicolumn{2}{c}{ t-test for Equality of Means } \\
\cline { 2 - 3 } & df & Sig. (2-tailed) \\
\hline Sub-Theme I & 73 & \\
Sub-Theme II & 73 & .000 \\
Sub-Theme III & 73 & .000 \\
\hline
\end{tabular}


Departing from the results in Table 3, it is apparent that: (1) the significance score of students' critical thinking skills for Sub-Theme I is 0.000 ; (2) the significance score of students' critical thinking skills for Sub-Theme II is 0.000; and (3) the significance score of students' critical thinking skills for Sub-Theme III is 0.000. Therefore, it might be concluded that the significance score of the students' critical thinking skills from the three sub-themes is lower than $0.050(0.000<$ 0.050 ). Consequently, $\mathrm{H} 0$ is rejected and thus there is a significant improvement on the students' critical thinking skills between the students who have been exposed to the product and the students who have not been exposed to the product. In other words, the scientific approach-based pictorial-storybook learning materials with the PjBL method might improve the students' critical thinking skills significantly. The significance might be seen on the test results of the students' critical thinking skills between the experimental group and the control group. The results of the paired sample t-test might be consulted in Table 4.

Table 4. Results of Paired Sample t-test for the Students' Critical Thinking Skills

\begin{tabular}{lcr}
\hline & \multicolumn{3}{c}{ t-test for Equality of Means } \\
\cline { 2 - 3 } & df & Sig. (2-tailed) \\
\hline Sub-Theme I & 49 & .000 \\
Sub-Theme II & 49 & .000 \\
Sub-Theme III & 49 & .000 \\
\hline
\end{tabular}

From the results in Table 4, it is apparent that: (1) the significance score of students' critical thinking skills for Sub-Theme I is 0.000; (2) the significance score of students' critical thinking skills for Sub-Theme II is 0.000; and (3) the significance score of students' critical thinking skills for Sub-Theme III is 0.000. Consequently, $\mathrm{H}_{0}$ is rejected and thus there is a significant difference before and after the students have been exposed to the product.

\section{Discussions}

Within the study the researcher has developed learning materials in the form of a scientific approach-based pictorial-storybook with the PjBL method for the students of the Second Grade. The development of the learning materials has gone through 10 stages of Borg \& Gall Model. Then, the learning materials are feasible for implementation since they have been validated by the material experts, the language experts and the results of FGD session.
Based on the assessment of the language expert, the learning materials that have been developed belong to the "Very Feasible" category. Similarly, based on the assessment of the material expert, the learning materials that have been developed belong to the "Very Feasible" category. In other words, the results of the assessment by the experts have shown that the scientific approach-based pictorial-storybook learning materials with the PjBL method have already met the requirements of feasibility for implementation. Within the product, there have already been the elements which define that the product might be implemented as learning materials and these elements are: (1) the aspect of content concordance; (2) the aspect of language; (3) the aspect of material presentation; and (4) the aspect graphic (Departemen Pendidikan Nasional Republik Indonesia, 2008, pp.3-28).

First, the aspect of content concordance or content feasibility consists of the following components: (1) concordance between the core competence and the basic competence; (2) concordance to the children development; (3) concordance to the needs toward learning materials; (4) truth of learning material substance; (5) benefits of knowledge expansion; (6) concordance to moral values; and (7) concordance to social values. Second, the aspect of language consists of the following components: (1) readability; (2) information clarity; (3) concordance to the principles of appropriate and acceptable Bahasa Indonesia; and (4) effective and efficient (clear and brief) use of language. Third, the aspect of material presentation consists of the following components: (1) clarity of the objectives that should be achieved; (2) presentation sequence; (3) provision of enthusiasm and enthusiasm; (4) interaction (provision of stimulus and response); and (5) information completeness. Fourth, the aspect of graphic consists of the following components: (1) use of font type and font size; (2) layout; (3) pictures and illustrations; and (4) design. The product that has been developed already contains all elements of the sufficient learning materials.

The product, or the scientific approachbased pictorial-storybook learning materials, has several advantages in comparison to the other types of pictorial storybook. The product contains the scientific activities that imply the scientific approach and the activities of PjBL method that the characters perform in the story. Through these activities, the characters indirectly invite the readers, in this case the students, to join 
them to solve the problems that the characters have encountered. As having been reported by Gülbahar \& Tinmaz (2006, p.310), the projectbased learning process is peculiar namely that the project-based learning process centres on the students and focuses on the events or the problems. Through the project-based learning process, the students are demanded to solve the events or the problems that they have encountered by applying the principles or the concepts that they have studied. Thus, the project-based learning process encourages the students to be involved into constructive activities and the learning process becomes realistic.

As having been implied, the pictorialstorybook that has been developed contains the scientific approach and the PjBL method. The scientific approach consists of five scientific activities namely observing, raising questions, gathering information, associating and communicating. On the other hand, the PjBL methods contains four activities namely preparation, design, implementation and communication. Both the scientific activities and the scientific approach might be combined and the results of the combination is the pictorial storybook. Then, the combination of the scientific activities, the scientific approach and the communication skills are as follows: (1) observing and raising questions might be included into preparation; (2) gathering information might be included into design; (3) associating might be included into the implementation; and (4) communicating might be included into communication. All of the combinations are made apparent in the pictorial storybook. As having been stated by LynchBrown \& Tomlinson (1998, p.8), many trade books contain information that is relevant to the topics studied in school; moreover, this information is presented through captivating, sometimes beautifully illustrated, narratives. Their statement implies that materials might be presented through stories in a storybook with wonderful and interesting package. Through such package, the students are indirectly invited by the characters in the stories within the pictorial storybook to perform the activities like the characters do. By doing so, the students indirectly develop their critical thinking skills. These results are in accordance to the results of the study by Kelemen, Emmons, Schillaci, \& Ganea (2014, pp.1-10).

The pictorial-storybook learning materials benefit the scientific approach with the PjBL method because the scientific approach is similar to the PjBL method and the similarities are: (1) the learning process centres on the students; (2) the learning process involves the scientificprocessing skills in constructing concepts, laws and principles; (3) the learning process involves potential cognitive process; and (4) the learning process improves students' intelligence, especially the critical thinking skills, and develop students' characters (Hosnan, 2014, p.36). Similarly, the objective of designing the scientific approach-based pictorial-storybook learning materials aims at developing the critical thinking skills. The development of the critical thinking skills is urgent to pursue because the critical thinking skills serve as the basis for completing the six main points of reasoning namely observing, analysing, evaluation, questioning, contextualizing and reflecting (Thyer, 2013, p.3). The six main points of reasoning might be elaborated further as follows: (1) observing refers to the act of defining the theme that will be observed, gathering information from multiple sources, ensuring that the information is relevant and conducting the intended observation; (2) analysing refers to the act of identifying the similarities or the contradictions and selecting the topic of problems based on the available information; (3) evaluating refers to the act of being able to discern information value, to discern information from opinion, to prioritize important information and to discern opinion from fact; (4) questioning refers to the act of gaining consideration on alternative possibilities and developing new hypotheses; (5) contextualizing refers to the act of gaining contextualization in relation to the consideration of history, ethics, politics, culture, environment and certain situations; and (6) reflecting refers to the act of raising questions, testing conclusions and reflecting the results from the questions and the conclusions.

Critical thinking might be considered as part of higher order thinking because through critical thinking the students are not only demanded to know the truth but also to prove the truth. As having been stated by Leicester \& Taylor (2010, p.2), critical thinking can be thought of a stool box of skills which children to think more deeply and clearly about what they believe (and what they read or are told in the media etc.) and about they should do. With regards to the statement, the objective of the research and development is to improve the students' critical thinking skills with the scientific approach-based pictorial-storybook learning materials with the PjBL method. The PjBL itself is related to the 
Jurnal Prima Edukasia, 7 (1), 2019 - 103

Dini Aria Farindhani, Muhammad Nur Wangid

activities of designing project-based products/ activities that a group might perform. Therefore, improving the critical thinking skills might not only be performed by individuals but also by groups of individuals. The statement is supported by the argument of Scott (2008, p.3), which states that the critical thinking skills should be integrated into other competencies such as group work. Thus, it might be implied that group activities that deal with the completion of a project might indirectly improve the students' critical thinking skills.

As having been explained, the study aims at developing the pictorial-storybook learning materials with the PjBL method for improving the students' critical thinking skills. The results of the research and development are in accordance to the results of the study by Helle, Tynjälä, \& Olkinuora (2006, pp.287-314), which state that the project-based research is able to provide concrete and holistic experience since the project-based learning process might be performed by integrating learning materials and, not to mention, the project-based learning process is able to help the students learn both independently and cooperatively. The project-based learning process emphasizes the students to perform practical activities, which might help the students to develop their critical thinking skills. Through the conduct of the practical activities, the students are demanded to apply their understanding in solving the problems that they find in the practical activities.

In order to identify the level of the students' critical thinking skills, the researcher administers the narrative test items in the begining and in the end of the product implementation. The pre-test is administered in order to measure the preliminary level of the students' critical thinking skills, while the post-test is administered in order to identify the level of the students' critical thinking skills after the treatment (the product that has been developed) has been implemented. Based on the results of the descriptive analysis, the students' pre-test score for SubTheme I is 11.34 , Sub-Theme II 11.90 and SubTheme III 12.70. On the contrary, based on the results of descriptive analysis as well the students' post-test score for Sub-Theme I is 16.92, Sub-Theme II 18.14 and Sub-Theme III 19.72. The significant increase on the students' score serves as the basis for developing the product further because the product has been proven effective to improve the students' critical thinking skills, especially the students of Second
Grade. Subsequently, the post-test results from the experimental group are sent into the effectiveness test by means of significance test with the assistance from the SPSS 20 for Windows. The significance test consists of two stage namely the independent sample t-test and the paired sample t-test. The results of individual sample t-test show that the significance value for the experimental group is 0.000 , while the results of the paired sample t-test show that the significance value for the experimental group is 0.000 . Since the significance test results show that the significance value is 0.000 or lower than $0.050(0.000<$ 0.050 ), it might be concluded that there has been significant difference between the pre-experiment group and the post-experiment group.

The scientific approach-based pictorialstorybook learning materials with the $\mathrm{PjBL}$ method have been able to develop the students' critical thinking skills within the study. The pattern of critical thinking skills should be taught as early as possible and this statement has been supported by Moore (2014, p.376), who argues that critical thinking skills refer to a cognitive mental process that might be implemented in solving problems, making decisions, raising questions, designing plans, defining assessments, regulating information and creating new ideas. It might be implied that an individual who regularly exercises his or her critical thinking skills might be assisted in solving a problem based on the facts, the quantitative consideration and the logical and accurate argument. Therefore, teaching critical thinking skills as early as possible is important so that the students will be able to easily solve the problems that they will encounter in the future.

The learning activities by means of $\mathrm{PjBL}$ method have challenged the students more in finding the solution of a problem by devising a project. During the conduct of the effectiveness test, $85.00 \%$ of the students follow the actions that the characters in the stories have performed and basically these actions are related to devising a project for solving a problem. At the beginning, prior to the project activities, the students encounter with a problem and they are demanded to solve the problem but most of the students do not know what they should do. However, after the students learn from the pictorial-storybook that contains numerous project-based activities the students exercise higher thinking skills. Afterward, whenever the students encounter a problem, they are able to devise the appropriate solution. In the same time, the PjBL method 
Jurnal Prima Edukasia, 7 (1), 2019 - 104

Dini Aria Farindhani, Muhammad Nur Wangid

might be implemented into the 2013 Curriculum because of its flexible nature. This finding is in accordance to the argument by Westwood (2008, p.33), which states that project-based learning method might be implemented into numerous curricula. Based on the statement, it is clear that the PjBL method is flexible and might be suitable for implementation into the 2013 Curriculum.

2013 Curriculum is identical to scientific approach within its learning process. The activities in both the scientific model and the PjBL method such as determining theme, developing questions for devising a project, applying science into the project and presenting the project results provide positive impact to the students' cognitive pattern. Within the learning process of scientific approach and PjBL method, the skills of interpreting, analysing, drawing conclusions, evaluating, reflecting and following up are necessary. These activities are in accordance to the pattern within the critical thinking skills and the argument of Fascione (2011, p.8), who states that within critical thinking skills students should be ale to perform interpretation, analysis, inference, explanation and self-regulation. Thereby, the activities that the students directly perform will be completely absorbed and might be applied into problem-solving activities in the future. In addition, Romanowski \& Nasser (2012, p.121) state that critical thinking demands that students be active, sceptical and aware of their own understandings of the world and the ideologies and knowledge that govern life experience.

\section{Conclusions}

The research and development results in the scientific approach-based pictorial-storybook learning materials with the PjBL method. According to the assessment by the material expert and the language expert and also the results of FGD session, the pictorial-storybook has been feasible for improving the critical thinking skills of the students from the Second Grade with "Very Feasible" category. In addition, the scientific approach-based pictorialstorybook learning materials with the $\mathrm{PjBL}$ method that has been developed is able to effectively improve the critical thinking skills of the students from the Second Grade.

\section{References}

Anisa, A. (2017). Meningkatkan keterampilan berpikir kritis peserta didik melalui pembelajaran IPA berbasis potensi lokal Jepara. Jurnal Inovasi Pendidikan IPA,
$3(1)$, $1-11$. doi:https://doi.org/10.21831/jipi.v3i1.860 7

Borg, W.R., \& Gall, M.D. (1983). Educational research. New York: Logman Inc.

Departemen Pendidikan Nasional Republik Indonesia. (2008). Panduan pengembangan bahan ajar. Jakarta: Departemen Pendidikan Nasional.

Dinni, H. N. (2018, February). HOTS (High Order Thinking Skills) dan Kaitannya dengan Kemampuan Literasi Matematika. In PRISMA, Prosiding Seminar Nasional Matematika (Vol. 1, pp. 170-176).

Dinni, H. N. (2018, February). HOTS (high order thinking skills) dan kaitannya dengan kemampuan literasi matematika. PRISMA, Prosiding Seminar Nasional Matematika, 1, 170-176

Donoghue, M. R. (2009). Language arts: integrating skills for classroom teaching. California: SAGE Publication.

Duran, T., \& Bosch, E. (2011). Before and after the picturebook frame: A typology of endpapers. New Review of Children's Literature and Librarianship, 17(2), 122143. https://doi.org/10.1080/13614541.2011.62 4927

Facione, P. A. (2011). Critical thinking: What it is and why it counts. Insight Assessment, 2007(1), 1-23.

Fithriyyati, N., \& Maryani, I. (2018). Science lesson plan evaluation for 7th grade secondary school: A learning process reflection. Psychology, Evaluation, and Technology in Educational Research, 1(1), 9-18.

doi:http://dx.doi.org/10.33292/petier.v1i1. 17

Gülbahar, Y., \& Tinmaz, H. (2006). Implementing project-based learning and e-portfolio assessment in an undergraduate course. Journal of Research on Technology in Education, 38(3), 309-327. https://doi.org/10.1080/15391523.2006.10 782462

Helle, L., Tynjälä, P., \& Olkinuora, E. (2006). Project-based learning in post-secondary education-theory, practice and rubber sling shots. Higher education, 51(2), 287- 
314. https://doi.org/10.1007/s10734-0046386-5

Hosnan, M. (2014). Pendekatan saintifik dan kontekstual dalam pembelajaran abad 21: Kunci sukses implementasi kurikulum 2013. Bogor: Ghalia Indonesia.

Juano, A., \& Pardjono, P. (2016). Pengaruh pembelajaran problem posing terhadap kemampuan berpikir kritis dan komunikasi matematis siswa kelas V SD. Jurnal Prima Edukasia, $4(1), \quad 46 \quad-\quad 53$. doi:https://doi.org/10.21831/jpe.v4i1.7801

Kelemen, D., Emmons, N. A., Schillaci, R. S, \& Ganea, P. A. (2014). Young children can be taught basic natural selection using a picture-storybook intervention. Psychological Science, 25(4), 893-902. https://doi.org/10.1177/095679761351600 9

Kurniasih, I., \& Sani, B. (2014). Sukses mengimplementasikan Kurikulum 2013: Memahami berbagai aspek dalam Kurikulum 2013. Surabaya: Kata Pena.

Leicester, M., Taylor, D. (2010). Critical thinking across the curriculum: Developing critical thinking skills, literacy and philosophy in the primary classroom. McGraw-Hill Education (UK).

Lynch-Brown, C., \& Tomlinson, C. M. (1998). Essentials of children's literature. Allyn \& Bacon.

Mergendoller, J. R., Markham, T., Ravitz, J., \& Larmer, J. (2006). Scaffolding project based learning: tools, tactics and technology to facilitate instruction and management. Buck Institute for Education Novato, California USA.

Moore, K. D. (2014). Effective instructional strategies: From theory to practice. Sage Publications.

Purnomo, H., \& Wilujeng, I. (2016). Pengembangan bahan ajar dan instrumen penilaian IPA tema Indahnya Negeriku penyempurnaan buku guru dan siswa Kurikulum 2013. Jurnal Prima Edukasia,
4(1),

67

78. doi:https://doi.org/10.21831/jpe.v4i1.7697

Rasiman, R. (2012). Penelusuran proses berpikir kritis dalam menyelesaikan masalah matematika bagi siswa dengan kemampuan matematika tinggi. Aksioma: Jurnal Matematika dan Pendidikan Matematika, 3(1). http://dx.doi.org/10.26877/aks.v3i1/Maret .221

Romanowski, M. H., \& Nasser, R. (2012). Critical thinking and Qatar's education for a new era: Negotiating possibilities. The International Journal of Critical Pedagogy, 4(1). http://hdl.handle.net/10576/4134

Rossiter, M. J., Derwing, T. M., \& Jones, V. M. (2008). Is a picture worth a thousand words?. Tesol Quarterly, 42 (2), 325-329.

Santrock, J. W. (2017). Educational psychology. McGraw-Hill Education.

Savage, M. P., \& Wehman, T. L. (2014). Assessing the impact of international experiential education on the critical thinking skills and academic performance of college students. International Journal of Arts \& Sciences, 7(1), 1-8.

Scott, S. (2008). Perceptions of Students' Learning Critical Thinking through Debate in a Technology Classroom: A Case Study. Journal of Technology Studies, 34(1), 3944.

Sinambela, P. N. (2017). Kurikulum 2013 dan implementasinya dalam pembelajaran. Generasi Kampus, 6(2), 17-29. Retrived from

https://jurnal.unimed.ac.id/2012/index.ph $\mathrm{p} / \mathrm{gk} /$ article/view/7085

Thyer, E. (2013). Development of the critical thinking teaching resource. Academic Assessment, Daekin University

Westwood, P. (2008). What teacher need to know about teaching methods. Cramberwell: Acer Press. 